\title{
The Evolution of Neurosurgery Throughout the Ages: From Trepanations in Prehistory to The Robotic Era
}

\section{A evolução da neurocirurgia ao longo das eras: Das trepanações pré-históricas à era robótica}

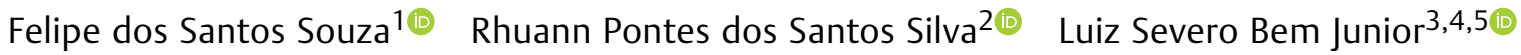

Hildo Rocha Cirne de Azevedo Filho $6,7,8$ (1)

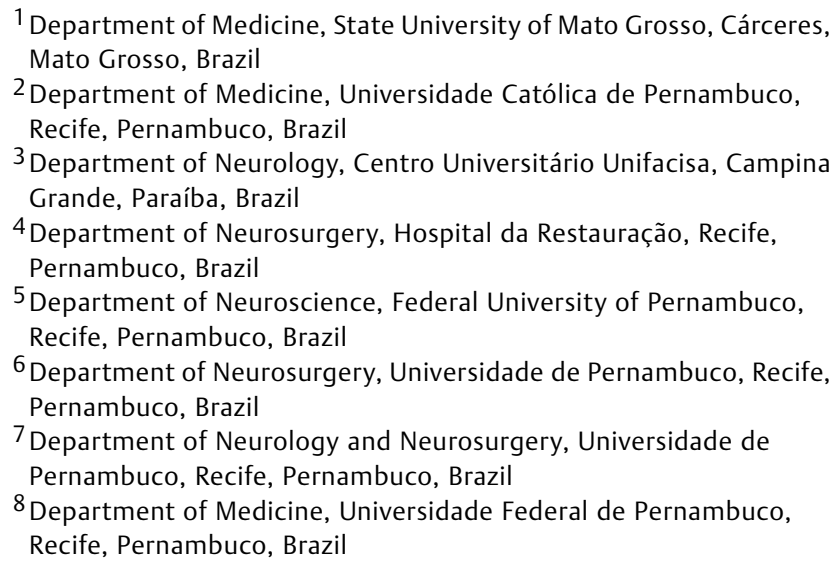

Address for correspondence Rhuann Pontes dos Santos Silva, medical student, Rua Professor Lobo de Miranda, 290, Dois Unidos Recife, Pernambuco 52160-070, Brazil (e-mail: rhuannpontes02@gmail.com).

Arq Bras Neurocir 2022;41(2):e153-e158.
Abstract
Keywords
- neuroanatomy
- history
- neurosurgery
- robotic surgical procedures

Introduction Throughout the historical course, the emergence of neurosurgery invariably involved the narrative about different eras, marked by relevant discoveries in the field of medical science. From prehistoric mystical and therapeutic reports to the Robotic Era in the $21^{\text {st }}$ century, there were changes that contributed to current neurosurgery. Thus, this study will analyze articles and studies that describe the history of neurosurgery and demonstrate the main advances in the field of science.

Materials and methods This is a narrative review of scientific literature, carried out by searching the following databases: Scientific Electronic Library Online (SCIELO), Online System for Searching and Analyzing Medical Literature (MEDLINE), Latin American Literature and Caribbean in Health Sciences (LILACS), and Public Medical Literature Analysis and Retrieval System Online (PubMed).The following descriptors were used: History of neurosurgery and Neuroanatomy, together with the Boolean operator "AND". In addition, the descriptors History of Neurosurgery and Robotics were used between the received

May 31, 2021

accepted

October 13, 2021

published online

February 25, 2022
DOI https://doi.org/ $10.1055 / \mathrm{s}-0042-1742424$. ISSN 0103-5355.

\footnotetext{
(c) 2022. Sociedade Brasileira de Neurocirurgia. All rights reserved. This is an open access article published by Thieme under the terms of the Creative Commons Attribution-NonDerivative-NonCommercial-License, permitting copying and reproduction so long as the original work is given appropriate credit. Contents may not be used for commercial purposes, or adapted, remixed, transformed or built upon. (https://creativecommons.org/ licenses/by-nc-nd/4.0/) Thieme Revinter Publicações Ltda., Rua do Matoso 170, Rio de Janeiro, RJ, CEP 20270-135, Brazil
} 


\section{Resumo}

\author{
Palavras-chave \\ - neuroanatomia \\ - história da \\ - neurocirurgia \\ - robotização
}

Boolean operator "AND". In this sense, in order to establish a linearity of the narrative presented, the evolution of neurosurgery in five eras was didactically separated.

Conclusion Neurosurgery, throughout history, has undergone several transformations. There was a series of events that made neurosurgery one of the most evolutionary and progressive sciences. This is because technology combined with scientific knowledge was, in fact, what made it possible to get where we are. In this sense, the studied ages allow the comprehension of a history that needs to be understood and valued by all students of the neurological and neurosurgical sciences.

Introdução Ao longo do percurso histórico, o surgimento da neurocirurgia envolveu invariavelmente a narrativa sobre diferentes épocas, marcadas por descobertas relevantes no campo da ciência médica. Desde relatos místicos e terapêuticos préhistóricos até a Era Robótica no século XXI, ocorreram mudanças que contribuíram para a neurocirurgia atual. Assim, este estudo analisará artigos e estudos que descrevem a história da neurocirurgia e demonstram os principais avanços no campo da ciência. Materiais e métodos Trata-se de uma revisão narrativa da literatura científica, realizada por meio de busca nas seguintes bases de dados: Scientific Electronic Library Online (SCIELO), Online System for Searching and Analyzing Medical Literature (MEDLINE), Literatura Latino-Americana e Caribenha em Ciências da Saúde (LILACS) e Public Medical Literature Analysis and Retrieval System Online (PubMed). Foram utilizados os seguintes descritores: "History of neurosurgery" e "Neuroanatomy", juntamente com o operador booleano "AND". Além disso, foram utilizados os descritores "História da Neurocirurgia" e "Robótica" entre o operador booleano "AND". Nesse sentido, para estabelecer uma linearidade da narrativa apresentada, separou-se didaticamente a evolução da neurocirurgia em cinco eras.

Conslusão A neurocirurgia, ao longo da história, passou por diversas transformações. Houve uma série de acontecimentos que fizeram da neurocirurgia uma das ciências mais evolutivas e progressivas. Isso porque a tecnologia aliada ao conhecimento científico foi, de fato, o que possibilitou chegar onde estamos. Nesse sentido, as idades estudadas permitem a compreensão de uma história que precisa ser compreendida e valorizada por todos os estudantes das ciências neurológicas e neurocirúrgicas.

\section{Introduction}

Throughout the historical course, the emergence of neurosurgery invariably involved the narrative about different eras, marked by relevant discoveries in the field of medical science. Prehistoric mystical and therapeutic reports document the first descriptions of primitive cranial surgical procedures, including cranial perforation, called trepanation, a procedure indicated for individuals with mental disorders, headaches and head injuries.

Harvey Cushing, a physician and neurosurgeon at Harvard University, marked the 20th century with his contributions that leveraged the history of medicine and made him one of the greatest references of all time. ${ }^{1}$ Among his achievements are the use of radiography in the diagnosis of brain tumors, the encouragement of studies and research on electroencephalic stimulation, and the demonstration of the importance of knowledge and control of intracranial pressure, contributing to the historical decrease in mortality from brain tumors, being, therefore, the precursor of a new era, the Cushing Era.
Still in the $20^{\text {th }}$ century, there was the advent of new imaging techniques, such as radiology and radiotherapy, allowing for better surgical outcomes and enabling the consolidation of neurosurgery as a well-defined specialty worldwide. In parallel to this, the development of new microsurgical techniques by M. Gazi Ysargil, a Turkish neurosurgeon, ushered in a new era in medicine. New surgical instruments were conceived, which transformed the scenario of surgical microanatomy and resolved technical limitations that, until then, made some patients inoperable. In 1980, there was a great advance in the history of medical science with the first use of robotics to perform neurosurgical biopsies, a fact of extreme importance that boosted the search for robotic systems that contributed to microsurgery. 2,3

In view of this, among prehistoric trepanations, the use of robots that respond to commands from neurosurgeons and perform complex microsurgery, there is a time and a space that must be understood on several aspects. In this context, the present study seeks, through a narrative review of the 
literature, to synthesize and discuss the main milestones in the evolution of neurosurgery throughout the ages, focusing on the current scenario of microsurgery and surgical robotization.

\section{Materials and Methods}

This is a narrative review of the scientific literature, carried out by searching the following databases: Scientific Electronic Library Online (SCIELO), Online System for Searching and Analyzing Medical Literature (MEDLINE), Latin American Literature and Caribbean in Health Sciences (LILACS), and Public Medical Literature Analysis and Retrieval System Online (PubMed). The searches were carried out in two stages in order to obtain better results in the literature. In the first analysis, the following descriptors were used: History of neurosurgery and Neuroanatomy, together with the Boolean operator "AND”. In addition, the descriptors History of Neurosurgery and Robotics were used between the Boolean operator "AND". Thus, the searches aimed to identify studies of systematic reviews and narratives that describe the history of neurosurgery throughout the ages and its advancement in the modern era. In this sense, in order to establish a linearity of the presented narrative, the evolution of neurosurgery in five eras was didactically separated: (a) medicine in the Pre-Cushing Era, (b) medicine in the Cushing Era, (c) medicine in the Yasargil Era, (d) medicine from the Endoscopic Era and, finally, (e) medicine from the Robotic Era.

The inclusion criteria were: articles that addressed the neurosurgery narratives, studies, and essays on the evolution of neurosurgery throughout history and systematic reviews that described the development of medicine according to historical periods. The exclusion criteria were: articles that did not contemplate the theme about the history, evolution, and development of neurosurgery in the course of history. Duplicates were also excluded.

\section{Results}

\section{Number of Studies}

A total of 28 studies were included.

\section{Discussion}

\section{Pre-Cushing Era}

Since the beginning, classical philosophers like Aristotle and Descartes have attributed important functions to the brain in cognitive control. In mythology, Egyptian society documented the first record of a surgical intervention in the spinal cord, in which the god Osiris was resurrected with Isis and Thoth, which reveals previous knowledge of neuroanatomy. ${ }^{1}$ In the real world, mysticism inspired neurosurgical and practical applications, such as cranial trepanations and craniectomies reported in the Neolithic period. ${ }^{2,3}$ Both procedures allowed the simple perforation of the skull, indicated for high-intensity headaches, convulsions, and changes in the mental picture, and the wider opening of the skull, called craniectomy, allowed bone regeneration over time and contributed to the history of neurosurgery. ${ }^{4}$
Around 300 BC, in the Egyptian city of Alexandria, anatomists such as Hippocrates and Erasistratus began dissecting criminals, which allowed greater anatomical knowledge and further spreading of the teaching of these human structures in schools and museums. ${ }^{5,6}$ Thus, it was possible to deepen the understanding of neuroanatomy, especially in the particularity of the grooves, gyres, and the description of the torula responsible for the union of venous sinuses.

In Greece, Plato and Democritus discussed the role of cognition with the human soul, framing the brain as part of the soul located in the head, while Galen, in Rome, disagreed with the correlation between gyrations and intellect, suggested by Erasistratus. ${ }^{7,8}$ Therefore, the era called pre-Cushing was marked by a great advance in the knowledge of neuroanatomy through dissections, mythology and philosophy that marked the history of neurosurgery. 9,10

\section{Cushing Era}

With the advent of the Middle Ages, little is known about the contribution to neurosurgical knowledge. Although science was abolished, especially by the Catholic Church, the first illustration of the human brain was obtained, in the $11^{\text {th }}$ century, and the first human dissections were performed in Europe. ${ }^{11,12}$ The scenario changed with the height of the Renaissance period, in which human dissection became legal and contributed to new surgical and anatomical foundations, such as the description of Sylvius groove by it. Thus, neuroanatomy has progressed in detailed descriptions throughout the $17^{\text {th }}, 18^{\text {th }}$ and $19^{\text {th }}$ centuries, ${ }^{13,14}$ beginning an era that bears the name of one of the most important names in the consolidation of neurosurgery as a medical specialty in the United States: Harvey Cushing.

At the beginning of the $20^{\text {th }}$ century, the Cushing Era begins with great contributions from the neurosurgeon who gives the name to the era, primarily due to the description of the treatment of traumatic brain injuries and missile injuries, but finds its peak in the 1930s with cerebral tumor surgery. ${ }^{15}$ Cushing was also responsible for mapping motor and sensory activities in different regions of the cerebral cortex, being one of the pioneers of cortical stimulation in epileptic patients.

\section{Yasargil Era}

The second half of the $20^{\text {th }}$ century enabled the advent of microneurosurgery with the leading role of the Turkish neurosurgeon M. Gazi Yasargil, who initiated the Yasargil Era. At the University of Basel, he had his first contact with microsurgery performing transpalatinal exploration of the hypophysis in frogs for research. The neurosurgical microscope was used for the treatment of acoustic neuromata through translabyrinthine and through the middle fossa, ${ }^{16,17}$ allowing the introduction of this equipment in the area of neurosurgery. In addition, Yasargil was responsible for developing techniques for vascular neurosurgery that started working on the middle cerebral arteries of dogs, transforming the prognosis of patients who until then were considered inoperable. ${ }^{18}$ Microsurgical instruments, retractors, floating microscope, and aneurysm clips were conceived by her. The 
technique for transplantation of the superficial temporal artery to the middle cerebral artery by end-to-side anastomosis was also developed by Yasargil.

Thus, the era of microsurgery enabled the detailed and meticulous study of brain areas, contributing to topographic reasoning and to the further development of more improved equipment in microsurgery. So, the neurosurgical procedures that are performed today has been affected by the work of this neurosurgeon.

\section{Endoscopic Era}

The advent of magnetic resonance imaging (MRI), from a surgical point of view, in addition to being an element of neuroimaging coupled to different stereotaxis systems, its digital image storage and manipulation base allowed and allows three-dimensional reconstructions to be easily created. With the different information obtained by the method, which can be observed from different points of view, thus lending itself and even simulations of accesses and surgical views. ${ }^{19}$ The digital basis of storage and manipulation of the different modalities of neuroimaging exams, associated with the technology of transmission of light pulses, culminated in the development of the so-called surgical neuronavigator, as idealized initially by Watanabe et al., in 1987, and which is characterized as being a stereotactic neuronavigation system. Having images obtained before surgery and related to cranial repair points in a computer station, whose position will be constantly updated during the surgical procedure, the neuronavigation system is able to identify, in the stored images, structures properly pointed in the surgical field, by means of a triangulation process similar to that used by the well-known navigation instrument called global positioning system (GPS).

With the development of optical and camera systems in the last 30 years, the endoscope has been added to the arsenal of neurosurgery techniques. Neuroendoscopy can be classified into: 1 ) pure neuroendoscopy: when the entire procedure is done under the view of the endoscope and the instruments pass through working channels coupled to the shirt or trocar that also contains the optics; 2) microsurgery controlled by endoscopy: where the endoscope serves as an instrument of magnification and illumination replacing the microscope, but the surgical instruments are the same as those used in conventional microsurgery and penetrate the field parallel to the endoscope; 3 ) endoscopy-assisted microsurgery: where the entire procedure is performed as in conventional microsurgery and the endoscope serves as an aid to view portions of the operative field to which the microscope does not allow access (AMATO, 2016). Currently, there is already an endoscope model that allows the use of an ultrasonic aspirator inside, increasing the efficiency of resection.

\section{Robotic Era}

Kwoh et al. were the pioneers in using a robotic system in surgery. They adapted an industrial system produced by Unimation, the PUMA 200, whose function was to position and align the trajectory of a stereotaxic biopsy cannula. ${ }^{20}$ The development of several systems for stereotaxic surgery followed, one of them a precursor to NeuroMate by Benabid et al. in $1987 .{ }^{21}$ Later, due to the need for precision and the potential impact of the displacement of intracranial structures during the surgical procedure, systems compatible with the acquisition of intraoperative image emerged. Minerva (University of Lausanne, Switzerland) was created with the purpose of operating inside a computed tomography device, allowing the acquisition of intraoperative images in real time $1987 .^{22,23}$

Subsequently, systems compatible with intraoperative MRI were created by the Universities of Harvard, Tokyo and Calgary $1987 .^{24}$ More recently, in addition to new stereotactic surgery systems such as NeuroMate and PathFinder, systems with other neurosurgical applications have also been developed, such as microsurgery (for example, NeuRobot and neuroArm), spinal surgery (SpineAssist) and radiosurgery (CyberKnife). ${ }^{25}$

Unlike stereotactic surgery, the systems used in microsurgery are passive. They are typically controlled remotely through a console, which can present an input mode similar to surgical instruments, which makes the task more intuitive for the surgeon. ${ }^{26,27}$ This way, the surgeon will be away from the operative field during the procedure. The console includes a monitor that transmits visual information to the surgeon, coming from a video camera built into the system. Often, a system of visualization in three dimensions is used, which allows a better perception of depth.

The Era of Robotics included not only transformations (-Figure 1) in surgical procedures with greater precision, technology and effectiveness, but brought safety to the surgeon due to systems complementary to his practice that, in the past, were not available due to the gradual progress of a society that developed in the field of neurosurgery from trepanations to the use of robots in surgical interventions. In this sense, it is clear that the history of humanity over the historical eras also reflects the evolution of a scientific field increasingly marked by the robotization technique (-Figure $\mathbf{2}$ ).

\section{Conclusion}

Neurosurgery, throughout history, has undergone several transformations. From trepanations, skull perforations, to the use of robotics, there was a series of events that made neurosurgery one of the most evolutionary and progressive sciences. Mystical accounts during the Pre-Cushing Era boosted the execution of a historical narrative about the beginning of neurosurgery that started from anatomical descriptions about the peculiarity of the brain, but which is already consolidated in the Cushing Era when brain stimulation in epileptic patients becomes real. Furthermore, this is because technology combined with scientific knowledge was, in fact, what made it possible for us to get to where we are.

Era after era, passing through Yasargil, the microsurgery using microscopes also allowed, with cerebral mapping, to gain contours, definitions, names, and identifications more and more specific and significant. Vascular structures and 


\section{TEMPORAL EVOLUTION OF THE NEUROSURGERY ERAS}

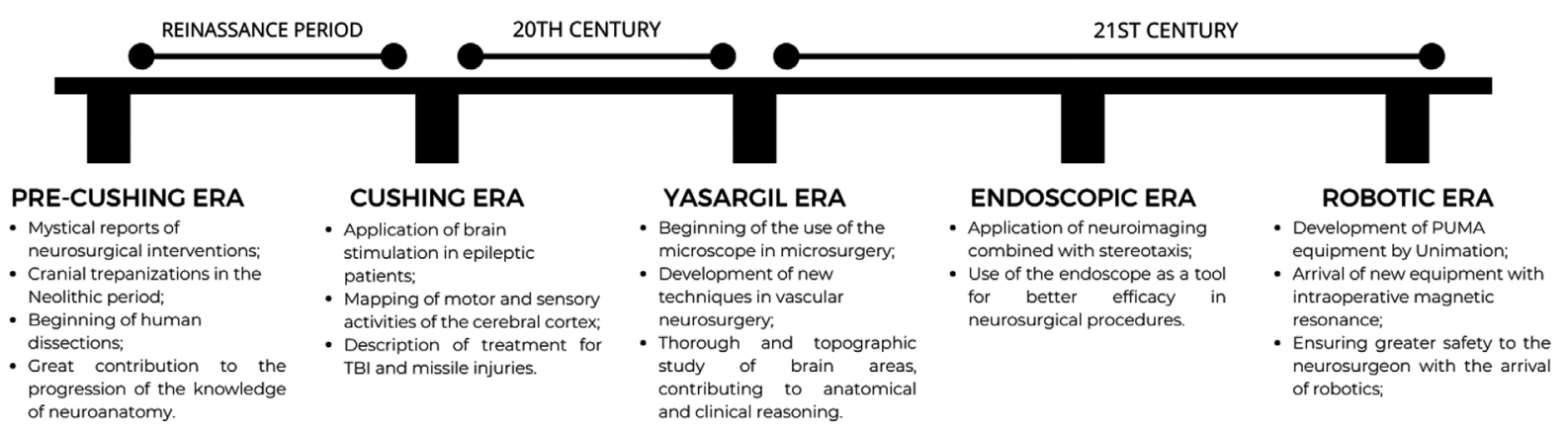

Fig. 1 Timeline with the main milestones of each era throughout the history of neurosurgery.

REINASSANCE

PERIOD

\section{TH CENTURY}

\section{TH CENTURY}

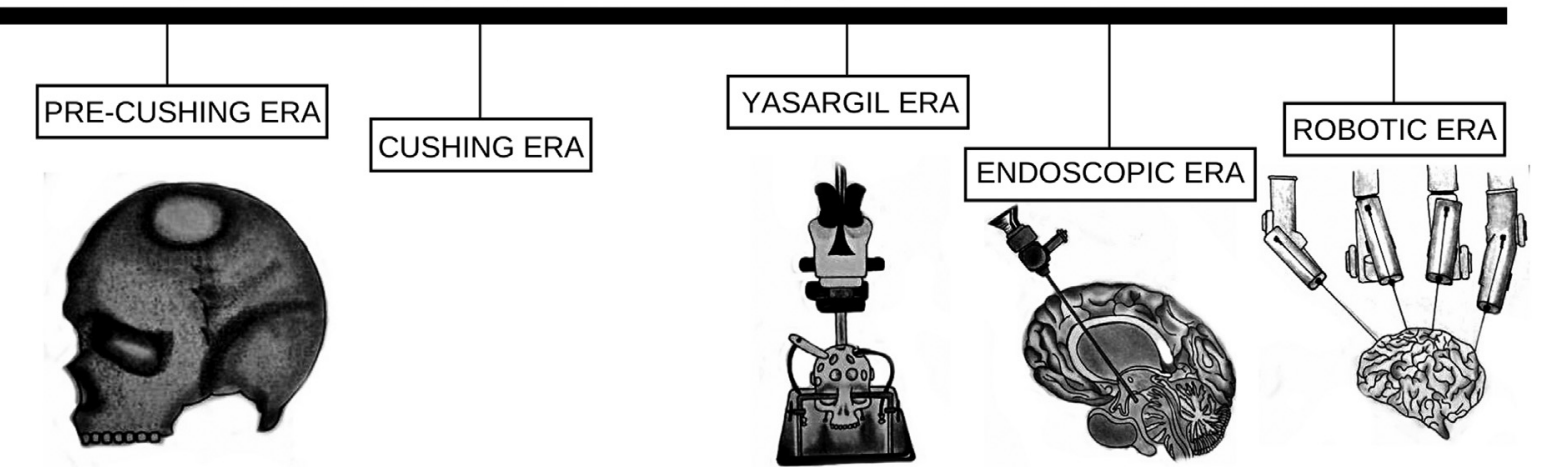

Fig. 2 Timeline illustrating the ages.

their ramifications, variations, and extensions have been described, and for this reason, detailed and topographic studies have become more accurate. In this sense, the studied ages allow the understanding of a history that needs to be understood and valued by all scholars of the neurological and neurosurgical sciences. From the Pre-Cushing era to the Robotic Era, many techniques, procedures, surgery systems, and scientific knowledge were achieved.

The application of neuroimaging linked to stereotaxic procedures was an indisputably unique advance regarding the success of neurosurgeries. The then Endoscopic Era used a device, called a neuroendoscope, which in a safe and minimally invasive manner brought the possibility of neurosurgeons to reach important territories such as those of the cerebral ventricles. Soon, many pathologies began to be treated, such as obstructive hydrocephalus, through an endoscopic third ventriculostomy. The Robotic Era, bringing intraoperative MRI with the procedures that, this time, with the arrival of robot- ics, brought not only safety to the neurosurgeon, but also better success, better chances of success, and expansion of the necessary interventions.

The present article allows not only a time travel around all the protagonists who have made neurosurgical science one of the most innovative and updated scientific fields, as well as through the historical landmarks that, from age to age, have been delimited and, gradually, led humanity to the point we have reached. The past, the present, and the future have never been described and analyzed in such a close and temporal way.

Contribution of the Authors

Study supervision: Bem Junior L. S. and Azevedo Filho H. R. C.;

Drafting of the first version of the article: Souza F. S. and Silva R. P. S;

Revision of the first draft: all authors;

Revision of the final version: all authors. 
158 The Evolution of Neurosurgery Throughout the Ages Souza et al.

\section{Conflict of Interests}

The authors have no conflict of interests to declare.

\section{References}

1 Greenblatt SH. "Contribuição paradigmática de Harvey Cushing para a neurocirurgia e a evolução de seus pensamentos sobre a especialização.". Boletim de História da Medicina, vol. 77 não. 4, 2003, p. 789-822. Projeto MUSE, Doi: 10.1353 / bhm.2003.0168

2 Simpson D. Neurosurgery in the age of Cushing: the achievement of Leonard Lindon. ANZ J Surg 2012;82(05):311-317. Doi: 10.1111/j.1445-2197.2012.06027.x

3 Nanda A, Filis A, Kalakoti P. Mythological and Prehistorical Origins of Neurosurgery. World Neurosurg 2016;89:568-573. Doi: 10.1016/j.wneu.2016.02.068

4 GONÇALVES Manuel de Almeida Ferreira. O estado da arte da robótica na neurocirurgia. 2014. Dissertação de Mestrado.

5 Cushing H. The meningiomas (dural endotheliomas): their source, and favoured seats of origin. Brain 1922;45(02):282-316. Doi: 10.1093/brain/45.2.282

6 ROMERO. Flávio Ramalho. Neurocirurgia e filosofia no século XIX: como o pensamento da época influenciou o desenvolvimento da neurocirurgia moderna. Arquivos Brasileiros de Neurocirurgia: Brazilian Neurosurgery 2015;34(03):258-262

7 Lovato RM, Vitorino Araujo JL, de Paula Guirado VM, Veiga JC. The Legacy of Yasargil: the Father of Modern Neurosurgery. Indian J Surg 2016;78(01):77-78. Doi: 10.1007/s12262-015-1421-6

8 Greenblatt SH. Harvey Cushing's paradigmatic contribution to neurosurgery and the evolution of his thoughts about specialization. Bull Hist Med 2003;77(04):789-822. Doi: 10.1353/bhm.2003.0168

9 Leblanc R. Cushing, Penfield, and cortical stimulation. J Neurosurg 2018;130(01):76-83. Doi: 10.3171/2017.7.JNS171256

10 Durante F. Contribution to endocranial surgery. Lancet 1887 ; 2:654-655

11 Keen WW. Three successful cases of cerebral surgery: including the removal of a large intracranial fibroma. Am J Med Sci 1888; 96:329-347

12 Robison RA, Taghva A, Liu CY, Apuzzo ML. Surgery of the mind, mood, and conscious state: an idea in evolution. World Neurosurg 2013;80(3-4):S2-S26. Doi: 10.1016/j.wneu.2013.08.002

13 Lehman RM, Augustine JR. Evolution and rebirth of functional stereotaxy in the subthalamus. World Neurosurg 2013;80(05): 521-533. Doi: 10.1016/j.wneu.2012.03.006
14 Rutka JT. Discovering neurosurgery: new frontiers. J Neurosurg 2011;115(06):1053-1066. Doi: 10.3171/2011.9.JNS111038

15 Moon K, Filis AK, Cohen AR. The birth and evolution of neuroscience through cadaveric dissection. Neurosurgery 2010;67(03): 799-809, discussion 809-810. Doi: 10.1227/01. NEU.0000383135.92953.A3

16 Ribas G. Das trepanações pré-históricas à neuronavegação: evolução histórica das contribuições da neuroanatomia e das técnicas de neuroimagem à prática neurocirúrgica. Arquivos Brasileiros de Neurocirurgia: Brazilian Neurosurgery. 2006;25:166-175. Doi: 10.1055/s-0038-1625500

17 Watanabe E, Watanabe T, Manaka S, Mayanagi Y, Takakura K. Three-dimensional digitizer (neuronavigator): new equipment for computed tomography-guided stereotaxic surgery. Surg Neurol 1987;27(06):543-547

18 YASARGIL MG, FOX JL, RAY MW. The operative approachto aneurysms of the anterior communicating artery. In: Krayenbül $\mathrm{H}$, (ed.): Advances and Technical Standards in Neurosurgery. Wien: Springer-Verlag; 1975:114-70

19 Yaşargil MG, Cravens GF, Roth P. Surgical approaches to "inaccessible" brain tumors. Clin Neurosurg 1988;34:42-110

20 LYONS AS. PETRUCELLI RJ: Medicine, an Illustraded History. New York: Abradale Press; 1978 1ed. New York: Abradale Press, 1978. pp. 616-48.

21 Jr RHOTON. AL: General and micro-operative techniques. InYoumans JR, (ed.): Neurological Surgery. 4. ed. Philadelphia: WB Saunders; 1999:724-66

22 RIBAS GC. RODRIGUES JUNIOR AJ, JANE JA: The central lobe concept. J Neurosurg

23 Macbeth J, Carson D, Northcote J. Social Capital, Tourism and Regional Development: SPCC as a Basis for Innovation and Sustainability. Curr Issues Tour 2004;7(06):502-522. Doi: $10.1080 / 1368350050408668200$

24 Ponnusamy K, Mohr C, Curet MJ. Clinical outcomes with robotic surgery. Curr Probl Surg 2011;48(09):577-656. Doi: 10.1067/j. cpsurg.2011.05.002

25 Tamraz JC, Comair YG (2000). Atlas of Regional Anatomy of the Brain Using MRI. Berlin; New York, NY: Springer

26 Finger M. From Knowledge to Action? Exploring the Relationships Between Environmental Experiences, Learning, and Behavior. J Soc Issues 1994;50(03):. Doi: 10.1111/j.1540-4560.1994.tb0 2424.x

27 Medicine: An Illustrated History. By Albert S. Lyons and R. Joseph Petrucelli, 11. 616 pp. New York Harry N. Abrams, 1978 